\title{
PERBEDAAN PROTEIN URINE IBU MUDA DENGAN LANSIA DI DESA KEDUNGPANDAN, KEC. JABON, SIDOARJO
}

\section{THE DIFFERENCE OF URINE PROTEIN BETWEEN YOUNG MOTHER AND ELDERLY MOTHER IN KEDUNGPANDAN VILLAGE, JABON DISTRICTS, SIDOARJO}

\author{
Andreas Putro Ragil Santoso', Devyana Dyah Wulandari' \\ ${ }^{1}$ Prodi Analis Kesehatan, Fakultas Kesehatan, Universitas Nahdlatul Ulama Surabaya
}

\begin{abstract}
The body's protein functions greatly in the metabolic process and will be utilized by the body, especially tissues in the process of bodily activities, but over time the body will experience changes in activity. As you age, more and more tissue will also be inactive. This study aims to determine whether there is a difference in urine protein of young mothers with the elderly in Kedungpandan village, Kec. Jabon, Sidoarjo. The study design used analytic observation with cross sectional approach. The study population was 38 and determined based on the Slovin formula determined 33 samples, namely 33 elderly samples and 33 samples of young mothers. The sampling technique is done using probability sampling techniques. The results of research conducted based on the Mann-Whitney test showed that $p>0.05$ ie 0.379 showed that there was no difference between urine protein in young mothers and urine protein in the elderly in Kedungpandan village, Jabon district, Sidoarjo
\end{abstract}

Keywords: Urine Protein, Young Mother, Elderly

\begin{abstract}
ABSTRAK
Protein tubuh berfungsi besar dalam proses metabolisme dan akan dimanfaatkan tubuh terutama jaringan dalam dalam proses aktifitas tubuh, namun seiring berjalannya waktu dan usia tubuh akan mengalami perubahan aktifitas. Semakin bertambah usia semakin banyak jaringan juga akan mengalami inaktif. Penelitian ini bertujuan untuk mengetahui ada tidaknya perbedaan protein urine ibu muda dengan lansia di desa kedungpandan, Kec. Jabon, Sidoarjo. Desain penelitian digunakan observasi analitik dengan pendekatan cross sectional. Populasi penelitian adalah 38 dan ditentukan berdasar rumus slovin ditentukan 33 sampel yaitu 33 sampel lansia dan 33 sampel ibu muda. Teknik pengambilan sampling dilakukan menggunakan teknik probability sampling. Hasil penelitian yang dilakukan berdasarkan uji Mann-Whitney menunjukkan bahwa $\mathrm{p}>0,05$ yaitu 0,379 menunjukkan bahwa tidak ada perbedaan antara protein urine pada Ibu muda dengan protein urine pada lansia di desa Kedungpandan, Kec Jabon, Sidoarjo
\end{abstract}

Kata Kunci : Protein Urine, Ibu Muda, Lansia 


\begin{tabular}{ll}
\hline Alamat Korespondensi & : Fakultas Kesehatan, Universitas Nahdlatul Ulama Surabaya \\
Email & : Andreasprs87@unusa.ac.id \\
\hline
\end{tabular}

\section{PENDAHULUAN}

Protein adalah blok pembangun pada semua bagian tubuh, termansuk otot, tulang rambut dll. Protein dalam darah juga memiliki fungsi penting dalam melindungi tubuh, Protein mengandung unsur karbon, hydrogen, oksigen dan nitrogen yang tidak dimiliki lemak dan karbohidrat selain itu molekuk protein juga mengandung fosfor, belerang serta logam besi dan tembaga (Budianto, 2009). Protein merupakan polimer asam amino yang diikatkan oleh ikatan peptide dan merupakan senyawa paling banyak yang terdapat pada tubuh setiap manusia. Fungsi penting protein bagi tubuh salah satunya merupakan sebagai komponen untuk kontraksi otot sehingga memungkinkan untuk terjadi gerakan (Mark et.al, 2000). Kecukupan protein setiap orang berbeda didasarkan pada faktor berat badan, umur, jenis kelamin, serta jumlah jaringan tubuh yang masih aktif. Makin besar dan berat bobot tubuh seseorang, semakin banyak juga jaringan aktif maka makin banyak juga protein yang dibutuhkan oleh jaringan (Muchtadi, 2009). Pada lanjut usia akan terjadi proses menghilangnya kemampuan jaringan untuk memperbaiki diri atau mengganti pertahanan fungsi normal secara perlahan sehingga tidak dapat mempertahankan fungsi normal (Constantinides, 1994 dalam Sriwahyuni, 2011).

Protein urine merupakan protein yang ada dalam urine dalam keadaan abnormal akibat peningkatan jumlah protein dalam tubuh. Protein diuraikan menjadi asam amino oleh enzim esterase kemudian dirubah menjadi ammonia (NH3) selanjutya dibuang melalui urine (Gilman, 2006). Proteinuria di merupakan upaya yang diperlukan guna mendeteksi penyakit pada system urinarius baik yang disebabkan oleh kelainan fungsi ginjal maupun kelaian pada struktur (Loesnihari, 2012). Pemeriksaan urine dilakukan dengan beberapa cara diantaranya urine rutin dengan mengetahui sedimen urine, kimia urine menggunakan dipstick dan penggunaan sitopatologik khusus. Pemeriksaan urinalisis bukan bersifat diagnostik tetapi penanganan penyakit ginjal (Fuller, et al, 2001). Gangguan terjadi karena kelaianan struktur dan penurunan faal ginjal sehingga menyebabkan kelainan patologis komposisi darah, urine (Vassalotti, et al. 2016)

Berdasarkan Departemen Kesehatan RI tahun 2009 kategori usia dibagi berdasar masa dewasa pada usia 26 - 45 tahun sedangkan pada lansia 46 - 65 tahun. Pada masa usia dewasa perkemabangan terjadi untuk proses pendewasaan diri menimbukan aktifitas tubuh yang lebih demi mencapai tujuan, usia dewasa diharapkan bahwa individu sudah mampu menyelesaikan masalah sendiri. Lansia menunjukkan aktifitas individu sudah berkurang akibat dari adanya perubahan fisiologis (Depkes, 2009)

Kedungpandan merupakan salah satu Desa yang ada dikecamatan Jabon Kab. Sidoarjo. Desa Kedungpandan memiliki lingkungan yang cukup luas yang berdekatan dengan kabupaten pasuruan, Desa kedungpandan dibagi menjadi 2 wilayah besar yaitu kedungpandan dan telocor dimana masyarakat di wilayah kedungpandan matapencaharian beratni sedangkan wilayah tlocor merupakan wilayah tambak. 
Berdasarkan hal tersebut apakah ada perbedaan antara protein urine pada Ibu muda dengan lansia, dimana peningkatan jumlah protein urine terjadi pada usia lansia dikarenakan penggunaan protein didalam tubuh terutama tidak maksimal dikarenakan beberapa jaringan didalam lansia inaktif.

Penelitian ini bertujuan untuk mengetahui adanya perbedaan antara protein urine pada Ibu muda dengan lansia di desa kedungpandan, Kec Jabon, Sidoarjo.

\section{METODE PENELITIAN :}

Penelitian ini dilaksanakan di Desa Kedungpandan, Kecamatan Jabon Sidoarjo, Jawa Timur. Penelitian ini dilakukan secara langsung kepada responden yang datang dengan memberikan kuisioner yang selanjutnya diminta urine dari responden tersebut. Usia responden dibagi berdasarkan 2 sesuai dengan penelitian yaitu usia Ibu muda yaitu dibawah 50 tahun dan lansia diatas 50 tahun.

Desain penelitian digunakan observasi analitik dengan pendekatan cross sectional. Populasi penelitian adalah 38 dan ditentukan berdasar rumus slovin ditentukan 33 sampel yaitu 33 sampel lansia dan 33 sampel ibu muda. Teknik pengambilan sampling dilakukan menggunakan teknik probability sampling.

Variabel dependen merupakan pemeriksaan protein urine, sedangkan variabel independent yang digunakan adalah usia. Analisis penelitian menggunakan Analisa Man Whiteney untuk melihat perbedaan kedua variabel dan digunakan batas kemaknaan sebesar 0,05. Bila $\mathrm{p}<0,05$ maka dikatakan terdapat perbedaan namun jika $\mathrm{p}>0,05$ maka dinyatakan tidak terdapat perbedaan antar dua variabel.

\section{HASIL PENELITIAN}

\section{HASIL DAN DISKUSI:}

Penelitian ini dilakukan secara langsung kepada responden yang datang dengan memberikan kuisioner yang selanjutnya diminta urine dari responden tersebut. Usia responden dibagi berdasarkan 2 sesuai dengan penelitian yaitu usia Ibu muda yaitu dibawah 50 tahun dan lansia diatas 50 tahun.

Tabel 1. Distribusi Usia Pada Responden

\begin{tabular}{|c|c|c|c|}
\hline \multicolumn{2}{|c|}{ Usia } & Frekuensi & Presentasi (\%) \\
\hline Ibu muda & $<40$ & 17 responden & $51 \%$ \\
\hline & $>40$ & 16 responden & $49 \%$ \\
\hline Lansia & $<60$ & 21 responden & $63 \%$ \\
\hline & $>60$ & 12 responden & $37 \%$ \\
\hline
\end{tabular}

Berdasarkan Tabel 1. Menunjukkan bahwa data yang digunakan merupakan data yang diambil para responden sebesar 33 responden, dimana responden 1 dikelompokkan menjadi kelompok ibu muda yang dibagi menjadi 2 yaitu usia dibawah dan diatas 40 tahun, sedangkan responden ke 2 dikelompokkan menjadi kelompok lansia yaitu usia diatas dan dibawah 60 tahun. 
Tabel 2. Hasil Pemeriksaan Protein Urine

\begin{tabular}{cccc}
\hline & \multicolumn{1}{c}{ Hasil } & Frekuensi & Presentasi (\%) \\
pemeriksaan & & $79 \%$ \\
\hline Ibu muda & Negatif (-) & 26 responden & $12 \%$ \\
& Positif (1+) & 4 responden & $3 \%$ \\
& Positif (2+) & 1 responden & $6 \%$ \\
\hline Lansia & Positif (3+) & 2 responden & $88 \%$ \\
& Negatif (-) & 29 responden & $3 \%$ \\
& Positif (1+) & 1 responden & $9 \%$ \\
\hline
\end{tabular}

Berdasarkan Tabel 2. Menunjukkan bahwa hasil kadar protein urine pada Ibu muda menunjukkan sebanyak 26 responden (negatif $79 \%$ ) dan 7 responden (positif 21\%) dari 33 responden atau $100 \%$. Sedangkan protein urine pada lansia didapatkan sebanyak 29 responden (negatif 88\%) dan 4 responden (positif $12 \%$ ) dari 33 responden atau $100 \%$.

Tabel 3. Hasil Mann Whitey

\begin{tabular}{lr}
\hline & \multicolumn{1}{c}{ Kadar } \\
\hline Mann-Whitney U & 482.000 \\
Wilcoxon W & 1043.000 \\
Z & -.879 \\
Asmp. Sig. (2-tailed) & .379 \\
\hline
\end{tabular}

Berdasarkan hasil uji Mann-Whitey menunjukkan bahwa hasil 0,379 yang menjukkan bahwa nilai signifikan $\mathrm{p}>0,05$ yang menunjukkan tidak ada perbedaan antara protein urine pada Ibu muda dengan protein urine

\section{DISKUSI HASIL}

Karakteristik Responden Berdasar Usia

Berdasarkan total responden yaitu 66 yang terbagi atas 33 responden Ibu muda dan 33 responden Lansia. Usia dalam peningkatan protein urine didasarkan pada aktifitas jaringan di dalam tubuh, usia semakin bertambah maka jaringan inaktif akan semakin bertambah normal (Constantinides, 1994 dalam Sriwahyuni, 2011)

Protein Urine

Berdasarkan penelitian didapatkan $21 \%$ positif pada Ibu muda sedangkan pada lansia terdapat $12 \%$ yang positif. Peningkatan protein dalam tubuh dikarena reabsorsi didalam tubuh yang rendah. Peningkatan protein yang terjadi tidak selalu dikarenakan kerusakan fungsi ginjal melainkan kondisi tubuh yang terjadi peningkatan protein didalam tubuh.

Penyebab protein urine positif dikarenakan konsumsi protein yang berlebih, demam tinggi, aktifitas fisik yang berat atau akibat gangguan ginjal dan infeksi saluran kemih. Faktor penyebab munculnya proteinuria diantaranya filtrasi glomerulus dan reabsorbsi protein tubulus. Preeklamsia terjadi proteinuria dikarenakan kecepatan filtrasi glomerulus yang menurun, seperti glomerulopati dengan berat molekul yang besar (Puspitaningrum dan Mustika, 2016). 
Proteinuria adalah protein yang disekresi melalui urine lebih dari $30-150$ mg perhari dan proteinuria merupakan penanda terjadinya gangguan pada ginjal. Jumlah protein yang abnormal merupakan tanda awal penyakit ginjal atau penyakit sintetik yang signifikan. Proteinuria bisa bersifat sementara, ostatik dan persisten (Bawazier, 2009)

Perbedaan Protein Urine Pada Ibu Muda Dengan Lansia

Berdasarkan Analisa kedua variabel menunjukkan bahwa hasil signifikansi p > 0,05 yaitu 0,379 yang menunjukkan tidak ada perbedaan antara Ibu muda dengan lansia. Penelitian yang dilakukan oleh sriwahyuni (2011) menunjukkan abhwa pada lansia terjadi peningkatan kadar protein urine pada lansia. Hal ini terjadi dikarenakan adanya perubahan fisiologi dari dalam tubuh. Akan tetapi dalam penelitian ini menunjukkan tidak ada perbedaan antara Ibu muda dengan lansia.

\section{SIMPULAN}

\section{SIMPULAN DAN SARAN}

Hasil penelitian yang dilakukan berdasarkan uji Mann-Whitney menunjukkan bahwa $\mathrm{p}>0,05$ yaitu 0,379 menunjukkan bahwa tidak ada perbedaan signifikan antara protein urine pada Ibu muda dengan protein urine pada lansia di desa Kedungpandan, Kec Jabon, Sidoarjo

\section{SARAN}

Penelitian selanjutnya dapat dibandingkan usia lansia dengan remaja

\section{UCAPAN TERIMA KASIH}

Ucapan terima kasih kepada :

1. Universitas Nahdlatul Ulama yang telah membiayai penelitian

2. Kelurahan Kedungpandan menerima dan membantu proses penelitian

\section{DAFTAR PUSTAKA}

Bawazier LA, 2009. Ginjal Hipertensi : Proteinuria.

Busianto AK, 2009. Pangan Gizi dan Pembangunan Manusia Indonesia : DasarDasar Ilmu Gizi.

Depkes RI, 2009. Kategori Umur

Fuller, Threatte, Herry. Basic examination of Urine. Clinical diagnosis and management by laboratory method $20^{\text {th }}$

Gilman A 2006. The mechanism of Diuretic Action of Carboniv Anhyrase Inhibitor

Loesnihari R, 2012. Peran Analisa Urine Pada Penanganan Penyakit Ginjal dan Traktus Urinarius

Mark DB, Mark AD, Smith CM, 2000. Biokimia Kedokteran Dasar. Jakarta : ECG Muchtadi, D. 2009. Pengantar Ilmu Gizi. Bandung : Alfabeta

Puspitaningrum D, Mustika D, 2016. Pemeriksaan kadar hemoglobin dan urine pada ibu hamil di Laboratorium kesehatan Terpadu UIMUS (Skripsi). Semarang; FIKKES Universitas Muhammadiyah Semarang.

Sriwahyuni, Eka, 2011. Gambaran Kadar Protein Dalam Urine Pada Lansia di panti Jompo Dharma Asih-Binjai 
Vassalotti, Centor, Turner, Raquel, Geer, Choi, Sequist. Practical approach to detection anda management of cronic kidney disease for the primary care clinican. 